\title{
Essential oil composition of Salvia fruticosa Mill. populations from Balkan Peninsula
}

\author{
Ivana Cvetkovikj”, Gjoshe Stefkov, Marija Karapandzova and Svetlana Kulevanova \\ ${ }^{1}$ Institute of Pharmacognosy, Faculty of Pharmacy, Ss. Cyril and Methodius University, \\ Majka Tereza 47, 1000 Skopje, R. Macedonia
}

Received: January 2015; Accepted: April 2015

\begin{abstract}
The aim of this study was to investigate the yield and chemical composition of the essential oil (EO) isolated from 19 different populations of Salvia fruticosa Mill. (Greek sage, Lamiaceae) from nine different regions of Albania and Greece. The EO yield ranged from $0.25 \%$ to $4.00 \%$. Eighteen of the total analyzed populations met the Ph.Eur.8.0 minimal requirements concerning the essential oil yield. Performing GC/FID/MS analyses, a total of 75 components were detected, representing 79.15-97.83\% of the oils. Thirteen components ( $\alpha$-pinene, camphene, $\beta$-pinene, myrcene, 1,8-cineole, $\gamma$-terpinene, cis-thujone, trans-thujone, camphor, terpinene-4-ol, trans-(E)-caryophyllene, aromadendrene and $\alpha$-humulene) were identified in all samples, with 1,8-cineole as a predominant constituent. Statistical analysis showed that the geographical origin of plants did not have significant influence on the variation in chemical composition of the Greek sage essential oil.
\end{abstract}

Key words: Greek sage, yield, GC/FID/MS, essential oil composition, Greece, Albania

\section{Introduction}

The genus Salvia L. from Lamiaceae is one of the largest genera in this family and includes around 1000 species that have almost cosmopolitan distribution (Kintzios, 2000). It is an important aromatic genus which is frequently used as herbal tea and as a source of essential oils and aroma chemicals (Karamanos, 2008). With significant economic importance are the pharmacopoeial herbs: $S$. fruticosa Mill. (Syn. S. triloba L. or Greek sage) and S. officinalis L. (Dalmatian, common or garden sage) (Kosar et al., 2005).

S. fruticosa is an endemic species of the Eastern Mediterranean basin (Ali-Shtayeh et al., 2000; Carmona et al., 2005; Elmann et al., 2009). Naturalized can be found in parts of the Western Mediterranean regions like Mal-

\footnotetext{
*ivanacvetkovikj@ff.ukim.edu.mk, ivanacvetkovikj@gmail.com
}

ta, Spain and Portugal. S. fruticosa is the most widespread sage species in Greece, forming extended populations in littoral areas of the mainland, as well as the Ionian and Aegean islands (Kintzios, 2000).

The leaves of this herb have been used for treatment of various skin, blood, and infectious ailments as well as ailments of the digestive, circulatory and respiratory systems (Ali-Shtayeh et al., 2000; Carmona et al., 2005). Greek sage posses hypoglycemic effect and can be used against inflammations, hepatitis, and tuberculosis (Pitarokili et al., 2003). On the other hand the essential oil (EO) showed good antimicrobial activity against food borne bacteria (Longaray Delamare et al., 2007) and has antifungal activity (Pitarokili et al., 2003). Numerous investigations have been reported dealing with the essential oil composition and their biological activity, often referring to the $S$. offcinalis species (Pierozan et al., 2009; Giweli et al., 2013).

However, to the best of our knowledge, there is limited information on the chemical composition of the essen- 
tial oil isolated from $S$. fruticosa from Balkan Peninsula. Therefore the aim of the present work was to assess and compare the oil yield and composition from Greece and Albania as native area of distribution of this herb.

\section{Experimental}

\section{Plant collection}

Plant samples were collected from 19 different (18 indigenous and one non-indigenous) populations of Salvia fruticosa Mill., Lamiaceae, from nine different locations from Greece and Albania. The leaves were air dried, packed in paper bags and kept in a dark and cold place until analysis. Plant identity was verified and voucher specimens were deposited at the Institute of Pharmacognosy, Faculty of Pharmacy, Skopje, R. Macedonia (Table 1).

\section{Essential oil isolation}

The EOs were isolated from dried, cut leaves, by hydrodistillation in all-glass Clevenger apparatus for 2 hours according to pharmacopoeial method (Ph. Eur. 8.0., 2014). The oil yield was measured and presented in Table 1 .

\section{Analysis of essential oils' chemical composition}

EO samples in hexane $(1: 1000)$ were analyzed on Agilent 7890A Gas Chromatography system equipped with FID detector and Agilent 5975C mass spectrometer. For that purpose, HP-5ms capillary column $(30 \mathrm{~m}$ x $0.25 \mathrm{~mm}$, film thickness $0.25 \mu \mathrm{m}$ ) was used. Analytical conditions were as follows: oven temperature at $60{ }^{\circ} \mathrm{C}(0 \mathrm{~min}), 3{ }^{\circ} \mathrm{C} /$ $\min$ to $240^{\circ} \mathrm{C}(1 \mathrm{~min})$ and at the end increased to $280^{\circ} \mathrm{C}$ at a rate of $10^{\circ} \mathrm{C} / \mathrm{min}(1 \mathrm{~min})$; helium as carrier gas at a flow rate of $1 \mathrm{ml} / \mathrm{min}$; injector temperature $220^{\circ} \mathrm{C}$ and that of the FID detector $270^{\circ} \mathrm{C}$. One $\mu$ l of each sample was injected at a split ratio of $1: 1$. The mass spectrometry conditions were: ionization voltage $70 \mathrm{eV}$, ion source temperature 230 ${ }^{\circ} \mathrm{C}$, transfer line temperature $280{ }^{\circ} \mathrm{C}$ and mass range from 50 - $550 \mathrm{Da}$. The MS was operated in scan mode.

\section{Identification of the components}

The compounds were identified on the basis of literature (Adams, 2007) and estimated Kovat's (retention) indices that were determined using a mixture of homologous series of normal alkanes (C9-C25) analyzed under Automated Mass Spectral Deconvolution and Identification System (AMDIS)' conditions. Confirmation was made by

Table 1. Sampling localities and essential oil (EO) yields of 19 Salvia fruticosa Mill. populations from Balkan Peninsula

\begin{tabular}{|c|c|c|c|c|c|c|}
\hline \multirow{2}{*}{ Population } & \multirow{2}{*}{ Country (Code) } & \multirow{2}{*}{ Locality } & Latitude & Longitude & \multirow{2}{*}{$\begin{array}{l}\text { Vouchers } \\
\text { specimens }\end{array}$} & \multirow{2}{*}{$\begin{array}{c}\text { EO Yield } \\
{[\%]^{1)}}\end{array}$} \\
\hline & & & $(\mathrm{N})$ & (E) & & \\
\hline ALB 1 & Albania (ALB) & Porto Palermo-Qeparo 1 & $42^{\circ} 03^{\prime} 09^{\prime \prime}$ & $19^{\circ} 49^{\prime} 45^{\prime \prime}$ & ALBStPQ1/11 & 2.80 \\
\hline ALB 2 & Albania (ALB) & Porto Palermo-Qeparo 2 & $42^{\circ} 03^{\prime} 09^{\prime \prime}$ & $19^{\circ} 49^{\prime} 45^{\prime \prime}$ & ALBStPQ2/11 & 2.60 \\
\hline ALB 3 & Albania (ALB) & Porto Palermo-Qeparo 3 & $42^{\circ} 03^{\prime} 09^{\prime \prime}$ & $19^{\circ} 49^{\prime} 45^{\prime \prime}$ & ALBStPQ3/11 & 2.75 \\
\hline ALB 4 & Albania (ALB) & Porto Palermo-Qeparo 4 & $42^{\circ} 03^{\prime} 09^{\prime \prime}$ & $19^{\circ} 49^{\prime} 45^{\prime \prime}$ & ALBStPQ4/11 & 3.40 \\
\hline ALB 5 & Albania (ALB) & Llogora & $40^{\circ} 11^{\prime} 55^{\prime \prime}$ & $19^{\circ} 34^{\prime} 21^{\prime \prime}$ & ALBStL1/11 & 0.25 \\
\hline ALB 6 & Albania (ALB) & Palase & $40^{\circ} 09^{\prime} 54^{\prime \prime}$ & $19^{\circ} 37^{\prime} 29^{\prime \prime}$ & ALBStP2/11 & 2.45 \\
\hline ALB 7 & Albania (ALB) & Dhermi & $40^{\circ} 09^{\prime} 00^{\prime \prime}$ & $19^{\circ} 38^{\prime} 00^{\prime \prime}$ & ALBStD3/11 & 2.10 \\
\hline ALB 8 & Albania (ALB) & Borsh & $40^{\circ} 03^{\prime} 45^{\prime \prime}$ & $19^{\circ} 51^{\prime} 24^{\prime \prime}$ & ALBStB4/11 & 1.70 \\
\hline ALB 9 & Albania (ALB) & Ilias-Vuno & $40^{\circ} 08^{\prime} 23^{\prime \prime}$ & $19^{\circ} 41^{\prime} 37^{\prime \prime}$ & ALBStIv5/11 & 2.05 \\
\hline ALB 10 & Albania (ALB) & l & l & / & ALBStK11/13 & 1.80 \\
\hline ALB 11 & Albania (ALB) & Dhermi & $40^{\circ} 09^{\prime} 00^{\prime \prime}$ & $19^{\circ} 38^{\prime} 00^{\prime \prime}$ & ALBStD1ju/13 & 2.50 \\
\hline ALB 12 & Albania (ALB) & Dhermi & $40^{\circ} 09^{\prime} 00^{\prime \prime}$ & $19^{\circ} 38^{\prime} 00^{\prime \prime}$ & ALBStD1m/14 & 1.60 \\
\hline ALB 13 & Albania (ALB) & Dhermi & $40^{\circ} 09^{\prime} 00^{\prime \prime}$ & 19³8’00" & ALBStD2ju/14 & 4.00 \\
\hline GR 14 & Greece (GR) & Kavoussi 1 & $35^{\circ} 07^{\prime} 00^{\prime \prime}$ & $25^{\circ} 51^{\prime} 00^{\prime \prime}$ & GRStK1/11 & 1.60 \\
\hline GR 15 & Greece (GR) & Kavoussi 3 & $35^{\circ} 07^{\prime} 00^{\prime \prime}$ & $25^{\circ} 51^{\prime} 00^{\prime \prime}$ & GRStK3/11 & 1.60 \\
\hline GR 16 & Greece (GR) & Rhizoscaro 1 & I & I & GRStR1/11 & 3.60 \\
\hline GR 17 & Greece (GR) & Rhizoscaro 2 & l & l & GRStR2/11 & 3.85 \\
\hline GR 18 & Greece (GR) & Vrysses 2 & $35^{\circ} 21^{\prime} 45^{\prime \prime}$ & $24^{\circ} 15^{\prime} 11^{\prime \prime}$ & GRStV2/11 & 1.20 \\
\hline GR 19 & Greece (GR) & Vrysses 3 & $35^{\circ} 21^{\prime} 45^{\prime \prime}$ & $24^{\circ} 15^{\prime} 11^{\prime \prime}$ & GRStV3/11 & 2.40 \\
\hline
\end{tabular}


comparing the mass spectra of the components present in the EOs with the reference spectra obtained from Nist, Wiley and Adams mass spectra libraries. Quantification of the EOs components was performed using the normalization method of the GC/FID peak areas without any correction factors.

\section{Statistical analysis}

The significance of differences between oil samples was tested by analysis of variance (ANOVA) using the package Excel for Windows 7 and represented by critical value of an F-test $(F)$ and statistical significance $(p)$. ANOVA was performed on the geographical origin of plants as grouping factor.

\section{Results and discussion}

\section{Essential oil yield}

The EO yield of 18 indigenous and one non-indigenous (commercial) population of Greek sage from nine different locations from Greece and Albania ranged from $2.50 \mathrm{ml} / \mathrm{kg}$ to $40.00 \mathrm{ml} / \mathrm{kg}(0.25-4.00 \%)$ (Table 1$)$. The highest yield was recorded in two $S$. fruticosa populations, one from Dhermi, Albania (ALB 13) and the other population from Vrysses, Greece (GR 17), while the lowest was found in the Albanian population (ALB 5) from Llogora. Eighteen of the analyzed 19 populations met the Ph.Eur.8.0 minimal requirements concerning the essential oil yield.

\section{EO composition}

Data analysis of the EO chemical composition revealed six different classes of components: monoterpene hydrocarbons $(\mathrm{MH})$, oxygen-containing monoterpenes (OMT), sesquiterpene hydrocarbons ( $\mathrm{SH}$ ), oxygen-containing sesquiterpenes (OST), diterpenes (D) and non-terpene components (NT). Generally, OMT was dominant fractions, present with more than $45 \%$ in all tested samples, followed by smaller amounts of MT or ST (Table 2). On the other hand, the diterpene chemical class was absent from two Greek populations (GR 14 and GR 17).

GC/FID/MS analyses of the isolated EOs revealed a total of 75 compounds representing $79.15-97.83 \%$ of the oils (Table 2). Thirteen components were detected in all analyzed EOs (Figure 1) with 1,8-cineole as predominant constituent. Eight components: $\alpha$-pinene (0.36-6.03\%), camphene (tr.-6.04\%), $\beta$-pinene (tr.-6.14\%), 1,8-cineole (23.71-58.95\%), cis-thujone (1.17-10.37\%), trans-thujone (0.95-4.07\%), camphor (tr.-19.19\%) and trans- $(E)$-caryophyllene $(0.57-15.96 \%)$ that were found in amounts higher than $3.00 \%$ were considered as principal components of Greek sage essential oils.

Our results are in full agreement with Giweli et al. (2013) who reported high amounts of 1,8-cineole, followed by camphor, $\beta$-pinene, myrcene and $\alpha$-pinene in their samples of $S$. triloba provided from Libya. Additionally, Kosar et al. (2005), confirmed 1,8-cineole and camphor as predominant constituents in their Turkish sage samples and the same applies for $S$. fruticosa from Greece (Pitarokili et al., 2003; Pavlidou et al., 2004). On the other hand, Longa-

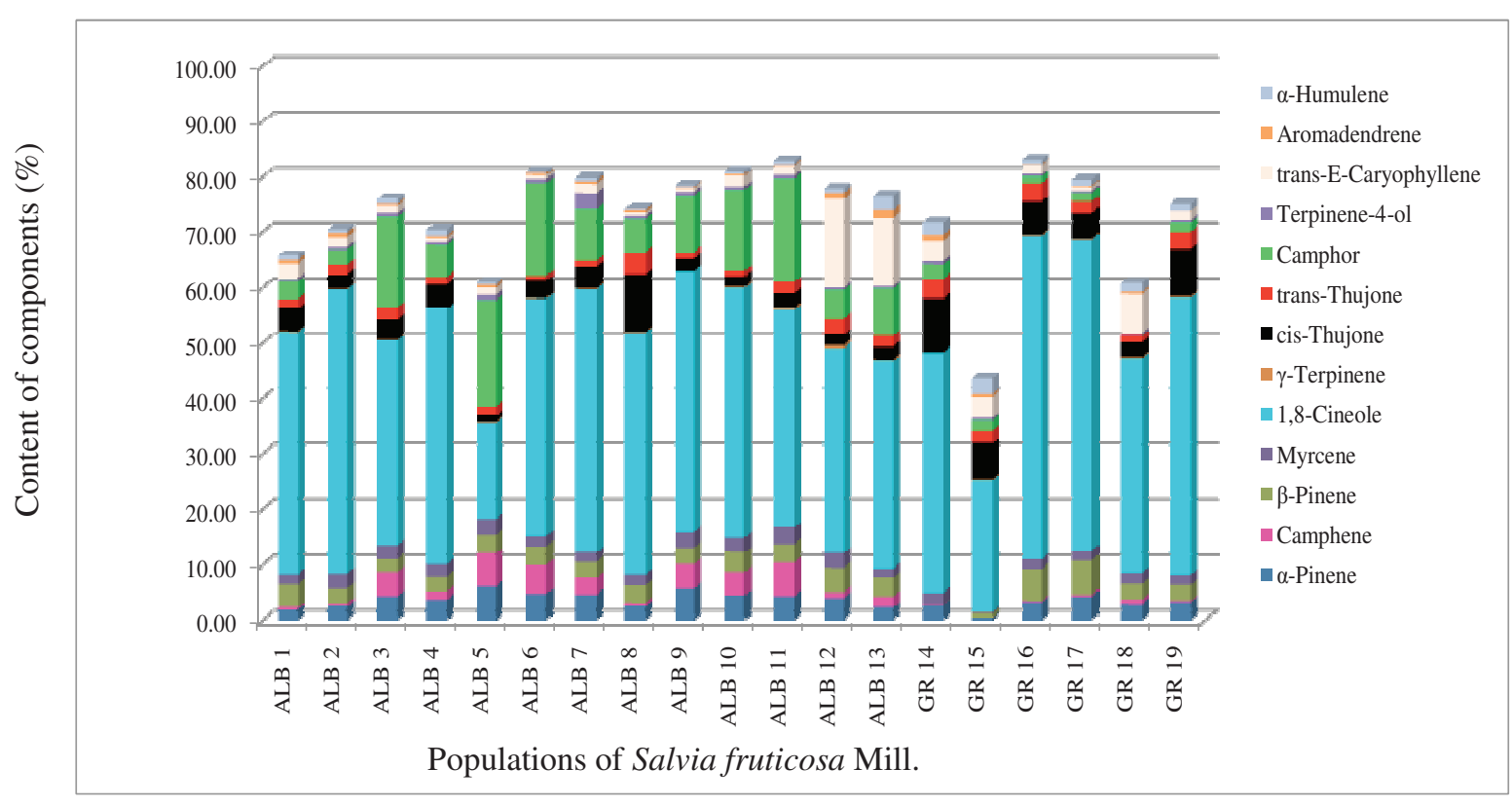

Fig. 1. Thirteen predominant EO constituents identified in all 19 populations of S. fruticosa Mill. 


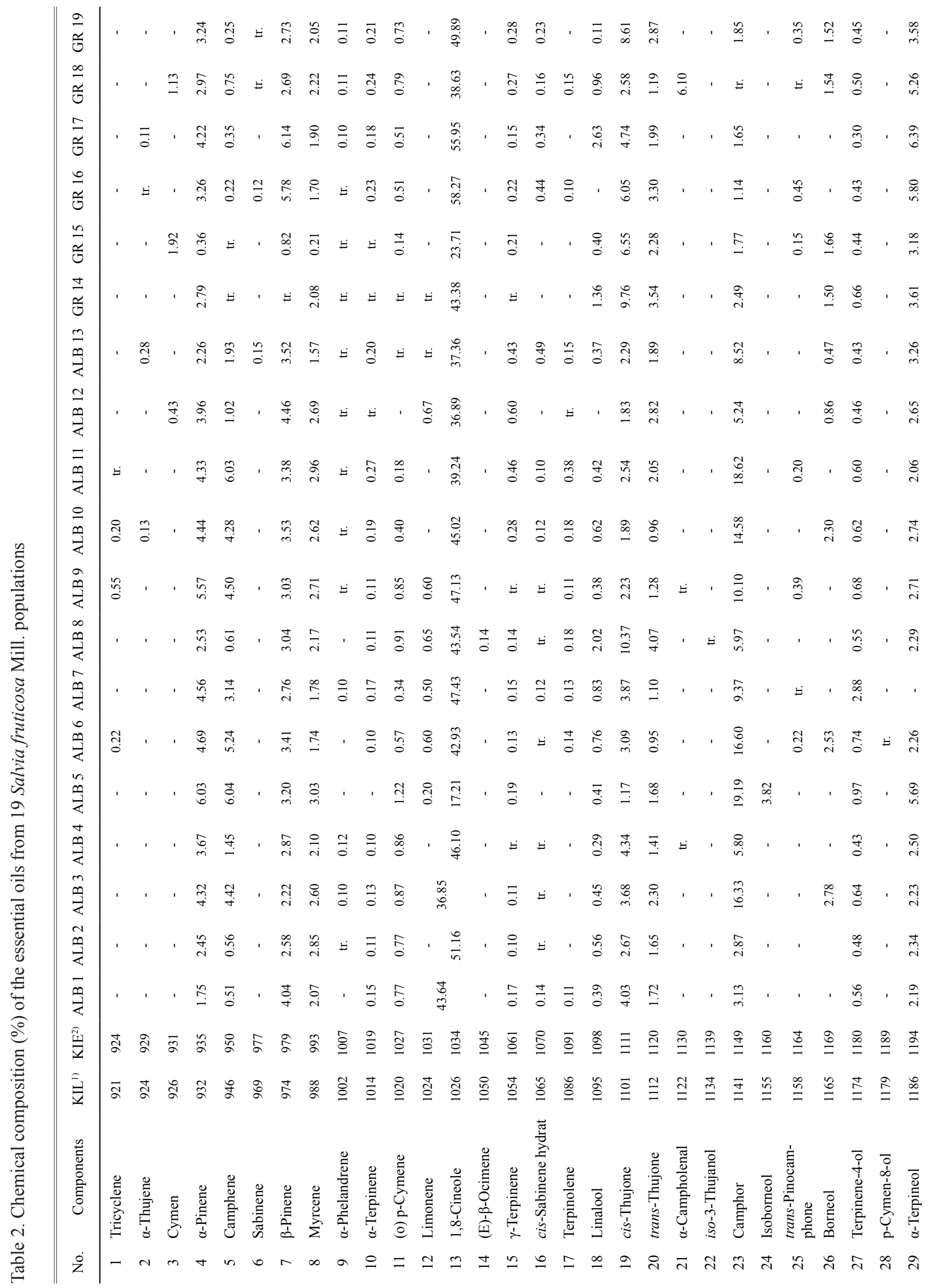

Maced. pharm. bull., 61 (1) 19 - 26 (2015) 


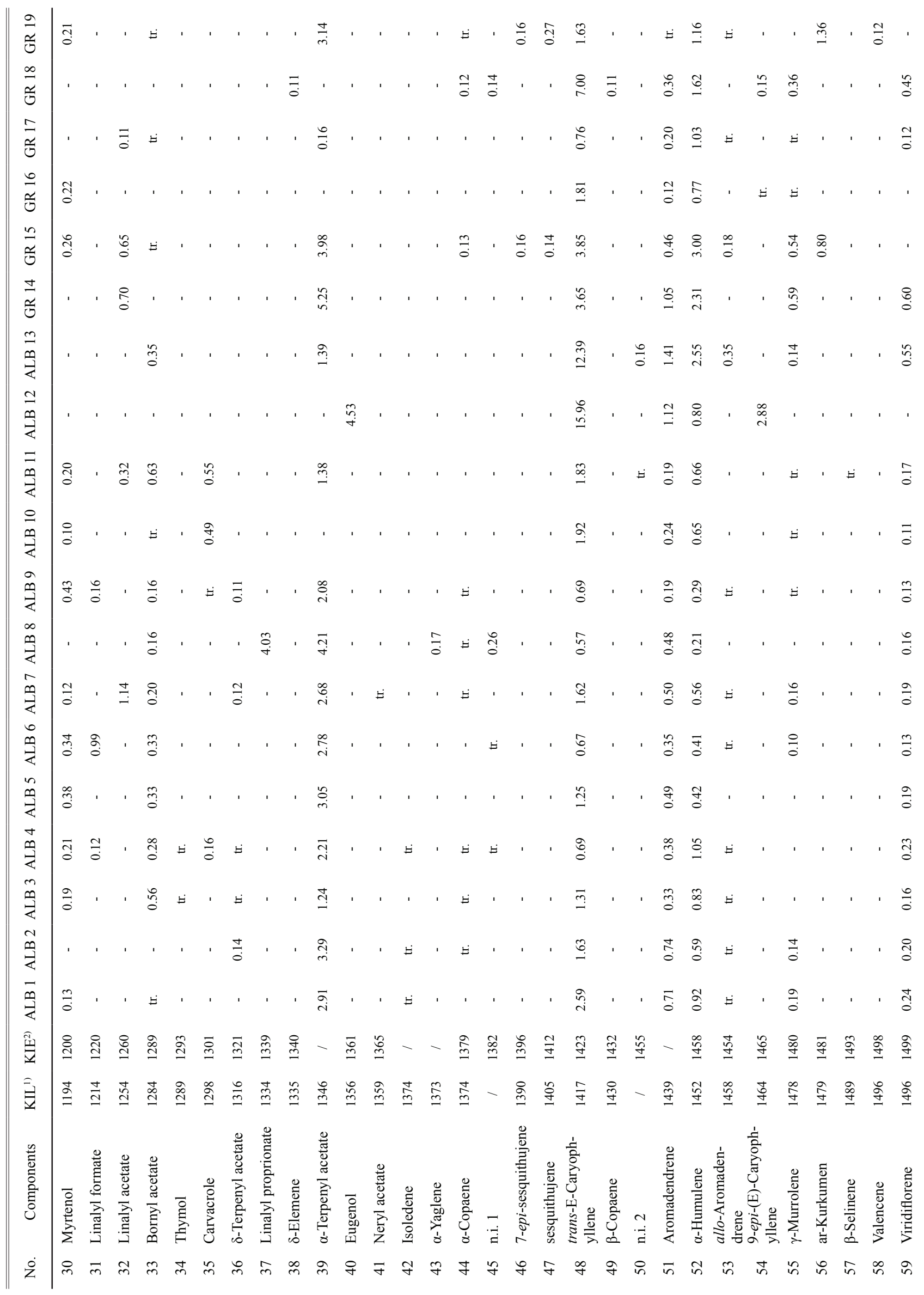

Макед. фарм. билт., 61 (1) 19 - 26 (2015) 


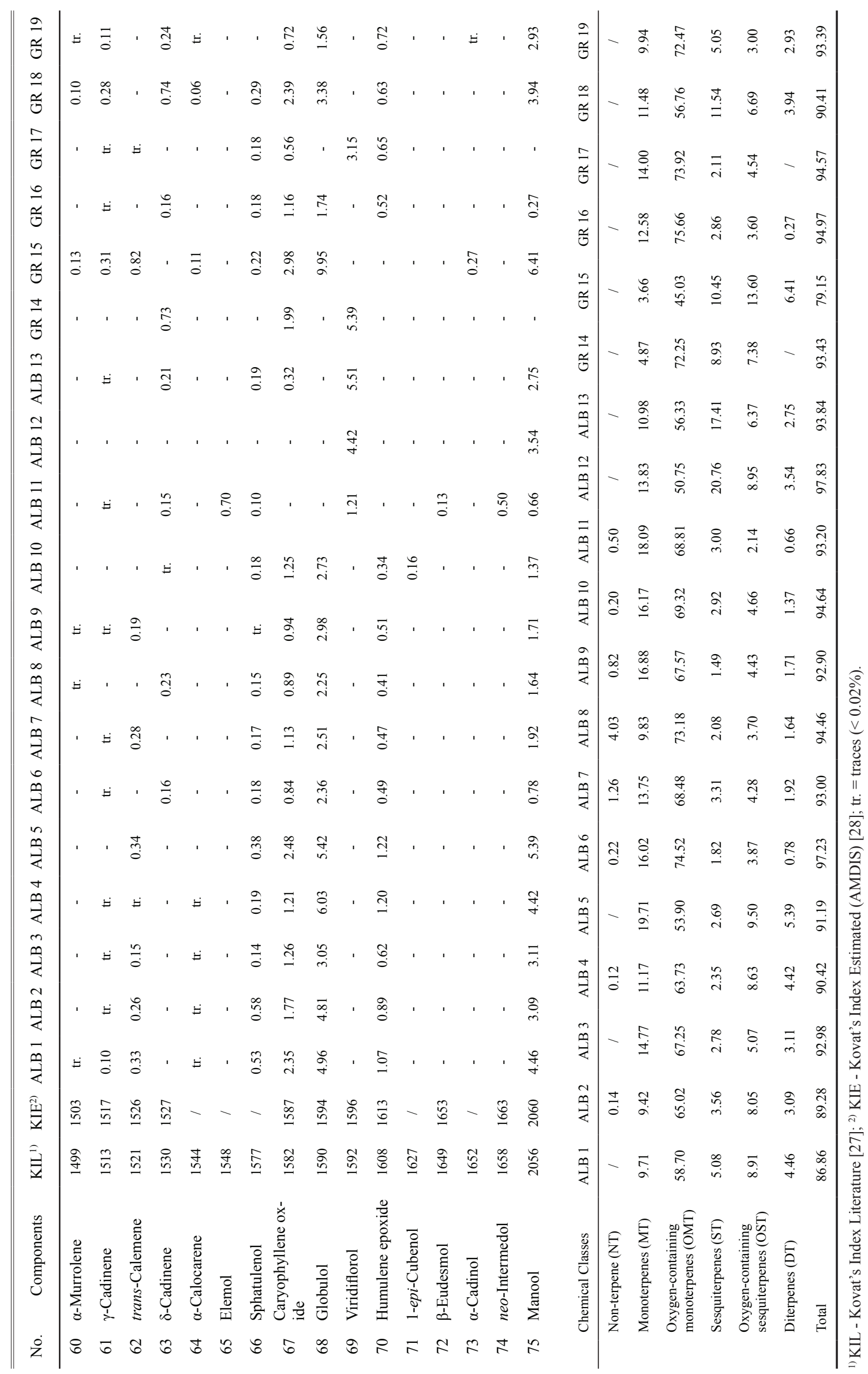

Maced. pharm. bull., 61 (1) 19 - 26 (2015) 
ray Delamare et al. (2007) and Pierozan et al. (2009) found $\alpha$-thujone as a major compound in their analyzed populations which is in contrast with our results and other available data.

Taking into concideration high cineole and camphor content, compounds with well established antibacterial properties, potential antimicrobial activity of the essential oil of $S$. fruticosa from Greece and Albania can be foreseen. Positive results of this activity could be used in the pharmaceutical industry, food production, and in the production of cosmetics or in any other purposes as substituted for S. officinalis.

Statistical analysis of variance (ANOVA) of the chemical composition of the essential oils for the complete data set of 19 samples revealed that there wasn't a statistically significant difference in the EO composition of $S$. fruticosa populations, regardless its origin.

\section{Conclusion}

The essential oils of 19 different populations of $S$. fruticosa was chemically analyzed and the oil yields were determinate and compared with the pharmacopeial requirements. The EO yield ranged from $0.25 \%$ to $4.00 \%$ and eighteen of the total analyzed populations met the minimal requirements $(\geq 1.20 \%)$. Regarding the chemical analysis, a total of 75 components were detected, and 13 components ( $\alpha$-pinene, camphene, $\beta$-pinene, myrcene, 1,8 -cineole, $\gamma$-terpinene, $c i s$-thujone, trans-thujone, camphor, terpinene-4-ol, trans-(E)-caryophyllene, aromadendrene and $\alpha$-humulene) were present in all samples. 1,8-Cineole was a predominant constituent in all sage populations, followed by camphor.

The results obtained from the essential oils isolated from Greek sage correlate with the available literature data, and the statistical analysis showed that the oil composition is not influenced by the geographical locations.

\section{Acknowledgements}

SEE-ERA.NET PLUS Joint Call project: ERA 64/01.

\section{References}

Adams, R.P., 2007. Identification of Essential Oil Components by Gas Chromatography/Mass Spectrometry. $4^{\text {th }}$ Ed. Illinois: Allured Publishing Corporation, IL, USA, pp 9-31.
Ali-Shtayeh, M.S., Yaniv, Z., Mahajna, J., 2000. Ethnobotanical survey in the Palestinian area: a classification of the healing potential of medicinal plants. J. Ethnopharmacol. 73, 22132.

Automated Mass Spectral Deconvolution and Identification System software (AMDIS ver.2.1.), National Institute of Standards and Technology (NIST), Standard Reference Data Program, Gaithersburg, MD (USA).

Carmona, M.D., Llorach, R., Obon, C., Rivera, D., 2005. "Zahraa", a Unani multi component herbal tea widely consumed in Syria: components of drug mixtures and alleged medicinal properties. J. Ethnopharmacol. 102, 344-50.

Elmann, A., Mordechay, S., Rindner, M., Larkov, O., Elkabetz, M., Ravid, U., 2009. Protective Effects of the Essential Oil of Salvia fruticosa and Its Constituents on Astrocytic Susceptibility to Hydrogen Peroxide-Induced Cell Death. J. Agric. Food Chem. 57, 6636-41.

European Pharmacopoeia, $8^{\text {th }}$ Edition, Council of Europe, Strasbourg, 2014.

Giweli, A.A., Dzamic, A.M., Sokovic, M., Ristic, M.S., Janackovic, P., Marin, P.D., 2013. The Chemical composition, antimicrobial and antioxidant activities of the essential oil of Salvia fruticosa Growing wild in Libya. Arch. Biol. Sci. 65, 32129.

Karamanos, A.J., 2008. Cultivation and breeding. The cultivation of Sage. In Kintzios SE (Ed.), SAGE "The Genus Salvia” (pp.93 - 108). Amsterdam: Harwood Academic Publishers.

Kintzios, S.E., 2000. SAGE "The Genus Salvia", Amsterdam: Harwood Academic Publishers.

Kosar, M., Tunalier, Z., Ozek, T., Kurkcuoglu, M., Husnu Can Baser, K., 2005. A simple method to obtain essential oils from Salvia triloba L. and Laurus nobilis L. by using microwave-assisted hydrodistillation. Zeitschrift fur Naturforschung C 60, 501-4.

Longaray Delamare, A.P., Moschen-Pistorello, I.T., Artico, L., Atti-Serafini, L., Echeverrigaray, S., 2007. Antibacterial activity of the essential oils of Salvia officinalis L. and Salvia triloba L. cultivated in South Brazil. Food Chem. 100, 603-8.

Pavlidou, V., Karpouhtsis, I., Franzios, G., Zambetaki, A., Scouras, Z., Mavragani-Tsipidou, P., 2004. Insecticidal and genotoxic effects of essential oils of Greek sage, Salvia fruticosa, and Mint, Mentha pulegium, on Drosophila melanogaster and Bactrocera oleae (Diptera: Tephritidae). J. Agric. Urban Entomol. 21, 39-49.

Pierozan, M.K., Pauletti, G.F., Rota, L., Atti dos Santos, A.C., Lerin, L.A., Di Luccio, M., Mossi, A.J., Atti-Serafini, L., Cansian, R.L., Oliveira, J.V., 2009. Chemical characterization and antimicrobial activity of essential oil of Salvia L. species. Ciencie e Technologia de Alimentos 29, 764-70.

Pitarokili, D., Tzakou, O., Loukis, A., Harvala, C., 2003. Volatile metabolites from Salvia fruticosa as antifungal agents in soil borne pathogens. J. Agric. Food Chem. 51, 3294-301. 
Резиме

\title{
Состав на етерично масло од популации на Salvia fruticosa Mill. од Балканскиот полуостров
}

\author{
Ивана Цветковиќ*, Ѓоше Стефков, Марија Карапанџова и Светлана Кулеванова

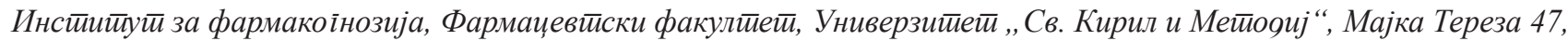 \\ 1000 Скойје, Рейублика Макеоонија
}

Клучни зборови: Грчка жалфија, принос, GC/FID/MS, состав на етерични масла, Грција, Албанија.

Целта на оваа студија беше да се испита приносот и хемискиот состав на етеричните масла изолирани од 19 различни популации на Salvia fruticosa Mill. (грчка жалфија, Lamiaceae) од девет различни региони од Р. Албанија и Р. Грција. Содржината на маслата се движи од $0,25 \%$ до 4,00\%. Осумнаесет од анализираните 19 популации одговараат на пропишаните минимални барања во европската фармакопеја за содржината на маслото. Сo GC/FID/ MS анализа на соодветните етерични масла, беа идентификувани вкупно 75 компоненти, што претставуваат 79,15$97,83 \%$ од вкупната содржина. Тринаесет компоненти ( $\alpha$-пинен, камфен, $\beta$-пинен, мирцен, 1,8 -цинеол, $\gamma$-терпинен, cis-тујон, trans-тујон, камфор, терпинен-4-ол, trans-(Е)-кариофилен, аромадендрен и $\alpha$-хумулен), се детектирани во сите примероци, а 1,8-цинеол е определена како најзастапена поединечна компонента. Статистичката анализа на резултатите покажа дека географското потекло на растенијата нема значајно влијание на варијациите во хемискиот состав на етеричното масло од S. fruticosa. 